\title{
Neutral endopeptidase (EC 3.4.24.11) in labial salivary glands in healthy controls and in patients with Sjögren's syndrome
} Yriö T Konttinen, Jyrki Törnwall, Pertti Kemppinen, Hannu Uusitalo, Timo Sorsa,
Mika Hukkanen, Julia M Polak

\begin{abstract}
Objective-Neuropeptides from nerve fibres can cause neurogenic inflammation. The potency of these peptides in vitro has led to the hypothesis that enzyme degradative systems are operative in vivo to limit their action. To consider this question neutral endopeptidase (NEP) in labial salivary glands in patients with Sjögren's syndrome was studied.

Methods-Synthesis of NEP mRNA in situ in labial salivary glands was studied using the reverse transcriptase polymerase chain reaction (RT-PCR). Immunohistochemical staining was used to localise the NEP enzyme protein and its neuropeptide substrates and fluorophotometry to measure the corresponding enzyme activities in saliva.

Results-NEP was found in nerve fibres and in perivascular, periductal, and periacinar axon terminal varicosities. Double labelling of PGP 9.5 and NEP confirmed this neuronal localisation of NEP. Although some fibroblast-like cells and occasional intravascular neutrophils were NEP positive, NEP mRNA was not found in labial salivary glands. Patients with Sjögren's syndrome and healthy controls did not have nerves containing NEP or neuropeptides (vasoactive intestinal peptide, substance $P$, or calcitonin gene related peptide (CGRP)) in lymphocyte foci. Salivary NEP activity was not decreased in patients compared with controls.
\end{abstract}

Conclusion-NEP in labial salivary glands is almost totally of neuronal origin and plays a part in proteolytic modulation of neuropeptides in salivary glands and saliva. These regulatory interactions seem to be altered in focal lymphocyte accumulations in Sjögren's syndrome.

(Ann Rheum Dis 1996; 55: 513-519)

Sjögren's syndrome is a systemic autoimmune disease of unknown aetiology. It is characterised by lymphocyte infiltrates, acinar atrophy, and disturbed function of exocrine glands. This results in keratoconjunctivitis sicca and xerostomia. ${ }^{1-6}$ Secretory function of exocrine glands is controlled by autonomic sympathetic and parasympathetic innervation. More recently, it has become evident that the autonomic nervous system, in addition to its role in an integrated vascular, secretory, and motor control of reflex salivary flow, also delivers trophic and regulatory neuropeptide stimuli to salivary gland parenchymal tissue. ${ }^{7-12}$ It has been shown that labial salivary gland tissue contains many neuropeptides which are able to modulate salivary gland functions. ${ }^{8-10}{ }^{12-20} \mathrm{By}$ contrast with classic biogenic amines, which are regulated by reuptake into nerve terminals, neuropeptide actions are rendered time specific and site specific by proteolytic degradation mediated by specific peptidases.

The neutral endopeptidase (NEP, EC 3.4.24.11, enkephalinase, CD10, or CALLA) cDNA sequence predicts a 750 amino acid integral membrane protein with a single hydrophobic 24 amino acid domain near the $\mathrm{NH}_{2}$ terminus that functions as a transmembrane anchor region. ${ }^{21-25}$ NEP is able to cleave neuropeptides and thus modulate the actions of neuropeptides, ${ }^{26-28}$ hormones, and immune mediators. ${ }^{26} 272930$ Despite its potentially important role in salivary gland function and pathology, the eventual presence and tissue distribution of NEP on cell membranes and saliva have not been studied. In this study NEP was studied in labial salivary glands and saliva at the mRNA, protein, and biochemical activity level. Changes associated with eventual disease were looked for by a comparison between healthy controls and patients with Sjögren's syndrome.

\section{Patients and methods}

SAMPLES AND BIOPSIES

All patients and controls participating in the present study received verbal and written information and gave their informed consent. The principles of the Declaration of Helsinki (Hong Kong amendment, September 1989) were followed throughout the work. The local ethics committee approved the study protocol. Collection of the animal material was approved by the local ethics committee and in the care and handling of animals the recommendations of the Strasbourgh Agreement (18 March 1986) were followed.

Labial salivary glands were obtained from 12 patients with primary Sjögren's syndrome and from eight normal controls. From each patient 5-10 labial salivary glands were taken under local anaesthesia as part of routine diagnostic

PO Box 9, FIN Anatomy,

University of Helskinki,

Finland.

Accepted for publication 3 April 1996 
procedure and fixed in Zambone's fluid for six hours. Preliminary studies had shown that snap frozen sections fixed in cold acetone gave staining artefacts in the form of diffusion of the NEP antigen; due to this diffusion artefact, it was not possible to localise NEP to peripheral nerve fibres. In acetone fixed tissue sections NEP seemed to be localised in extracellular periacinar and perivascular space and in nearby cells, as, for example, in pericytes around blood vessels. After a wash with $15 \%$ sucrose in $0 \cdot 1$ $\mathrm{M}$ phosphate buffered saline (PBS), $\mathrm{pH} 7 \cdot 4$ the glands were embedded in Tissue-Tek OCT compound (Lab-Tek Products, Division Miles Laboratories, Elkhart, IN, USA) and stored at $-70^{\circ} \mathrm{C}$ until analysed.

\section{IMMUNOHISTOCHEMISTRY}

Antibodies were purchased as follows: monoclonal mouse antihuman NEP of IgG $_{1}$ class from Dako a/s, Glostrup, Denmark; rabbit antihuman PGP 9.5 antiserum from Ultraclone, Cambridge, UK, and rabbit antihuman vasoactive intestinal peptide (VIP), CGRP, and substance $P$ from Cambridge Research Biochemicals, Cambridge, UK.

\section{IMMUNOPEROXIDASE METHOD}

Six $\mu \mathrm{m}$ thick sections were mounted on polyL-lysine (Sigma Chemicals Co, St Louis, MO, USA) coated slides. Endogenous peroxidase activity was blocked with $0.3 \% \mathrm{H}_{2} \mathrm{O}_{2}$ in methanol for 20 minutes followed by sequental incubations in normal horse serum (1:5) for 20 minutes, mouse antihuman NEP IgG 1 (1:200) for 60 minutes, biotinylated horse antimouse IgG (1:100) for 30 minutes, and avidin-biotinperoxidase complex (ABC) for 30 minutes. ${ }^{31}$ Finally, the section were incubated for five minutes in a chromogen solution of 3,3'-diaminobenzidine tetrahydrochloride (Sigma) in 0.006\% $\mathrm{H}_{2} \mathrm{O}_{2}$ solution in TBS $(0.05 \mathrm{M}$ tris hydroxymethyl]aminomethane, $0 \cdot 15 \mathrm{M}$ saline, $\mathrm{pH} 7 \cdot 4$ ) amplified with the glucose oxidase - nickel ammonium sulphate (Sigma) method. After each step, the slides were rinsed three times in PBS for five minutes each. All incubations were performed at $22^{\circ} \mathrm{C}$. Stained sections were dehydrated in ethanol, cleared in Inhibisol (Kalon Chemicals, Cramlington, UK), and mounted in Pertex (Histolab Products Ab, Gothenburg, Sweden). Neuropeptide (VIP, CGRP, and substance $P$ ) staining was performed as described in detail elsewhere. ${ }^{19}$

The staining controls used were $(a)$ omission of the primary monoclonal antibody from the staining sequence, and (b) replacement of specific monoclonal primary antibodies with inappropriate mouse myeloma protein. In addition, histochemical staining of untreated (no inhibition of endogenous peroxidase) tissue sections was carried out to show endogenous peroxidase.

INDIRECT DOUBLE LABELIING METHOD Six $\mu \mathrm{m}$ cryostat sections were cut and mounted on chrome-alum-gelatine coated glass slides and air dried for 60 minutes. Thereafter, sections were serially treated as follows: $5 \%$ normal swine serum in phosphate buffered saline (PBS) at $22^{\circ} \mathrm{C}$ for 30 minutes; rabbit antihuman PGP 9.5 antiserum (1:1000 in PBS) in a humid atmosphere at $4^{\circ} \mathrm{C}$ for 24 hours; after careful rinses with PBS, monoclonal mouse antihuman NEP antibodies (1:200 in PBS) in a humid atmosphere at $4^{\circ} \mathrm{C}$ for four hours; after careful rinses with PBS, biotinylated goat antirabbit IgG (RPN 1004; Amersham, UK; $1: 100$ in PBS with $1 \%$ bovine serum albumin or (PBS-BSA)) at $22^{\circ} \mathrm{C}$ for 60 minutes; after 60 minutes in PBS, fluorescein conjugated streptavidin (RPN 1232 Amersham, UK; $1: 100$ in PBS-BSA) at $22^{\circ} \mathrm{C}$ for 15 minutes; after 60 minutes in PBS, rhodamine TRITC conjugated goat antimouse IgG (Jackson Immunoresearch Lab Inc, PA USA; $1: 20$ in PBS) at $22^{\circ} \mathrm{C}$ for 60 minutes. After staining, the sections were thoroughly washed with PBS and mounted in glycerol-PBS (3:1). The specimens were viewed through a Leitz Aristoplan or Orthoplan epi-illumination fluorescence microscope equipped with filters allowing selective demonstration of FITC or TRITC.

\section{REVERSE TRANSCRIPTASE POLYMERASE CHAIN} REACTION (RT-PCR)

The RT-PCR was carried out on five patients with Sjögren's syndrome and five healthy controls. For each mRNA extraction nine 5 $\mu \mathrm{m}$ tissue sections were used. The mRNA was extracted using oligo (dT) ${ }_{25}$ covalently attached to superparamagnetic polystyrene microbeads via a $5^{\prime}$ linker group according to the manufacturer's protocol (Dynal, Oslo, Norway). Briefly, for each sample $30 \mu$ l of beads (binding capacity $2 \mathrm{ng}$ of poly(A) ${ }^{+}$ mRNA/ $\mu l$ beads) in suspension were pipetted into a sterile Eppendorf tube and placed in a magnetic particle collector. As the magnetic field of the collector attracted the beads to the wall, the supernatant was pipetted off from the opposite side. The Eppendorf tube was removed from the collector and $100 \mu \mathrm{l}$ of lysis/ binding buffer (100 mM Tris- $\mathrm{HCl}, \mathrm{pH} 8 \cdot 0$, $500 \mathrm{mM}$ LiCl, $10 \mathrm{mM}$ EDTA, pH $8.0,1 \%$ LiDS, $5 \mathrm{mM}$ DTT) was pipetted in to resuspend the beads. The buffer was pipetted off using the magnetic collector just before mixing with the sample. To the sectioned samples 100 $\mu l$ of lysis/binding buffer was added. After mixing and spinning, genomic DNA was sheared by passing the sample 10-15 times through a $1 \mathrm{ml}$ syringe with a $22 \mathrm{G}$ needle. The sample was incubated with the $(\mathrm{dT})_{25}$ beads for three minutes at room temperature under continuous gentle stirring, washed twice with $200 \mu \mathrm{l}$ washing buffer with $\mathrm{LiDS}$ ( $10 \mathrm{mM}$ Tris-

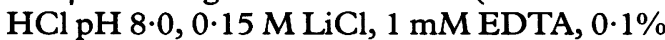
LiDS), twice with washing buffer without LiDS, and finally with $0.5 \times \mathrm{RT}$ buffer ( 45 $\mathrm{mM} \mathrm{KCl}, 5 \mathrm{mM}$ Tris- $\mathrm{HCl}, \mathrm{pH} 8 \cdot 3$ ).

The rTth reverse transcription (Perkin Elmer, Branchburg, NJ, USA) reaction was performed using $5 \mathrm{U}$ of the enzyme in a total volume of $20 \mu \mathrm{l}(90 \mathrm{mM} \mathrm{KCl}, 10 \mathrm{mM}$ 
Tris- $\mathrm{HCl}, \mathrm{pH} 8 \cdot 3,1 \mathrm{mM} \mathrm{MnCl}_{2}, 200 \mu \mathrm{M}$ of dATP, dCTP, dGTP, and dTTP) in thin wall PCR tubes (Plastic Trade, Helsinki, Finland) topped with $50 \mu 1$ mineral oil (Sigma) using a thermal cycler (Pharmacia, Sollentuna, Sweden). The reaction was run for one minute at room temperature, one minute at $37^{\circ} \mathrm{C}$, five minutes at $55^{\circ} \mathrm{C}$, and 10 minutes at $70^{\circ} \mathrm{C}$ with mixing at one minute intervals. After the first strand synthesis the beads were collected with the magnet, resuspended in $50 \mu l$ of TE buffer

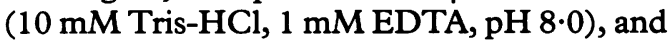
heated at $95^{\circ} \mathrm{C}$ for one minute. The beads were immediately collected using the magnet and the supernatant was pipetted off with aerosol resistant pipette tips (Molecular Bio-Products Inc, San Diego, CA, USA).

Target specific primers were designed based on published $\mathrm{cDNA}$ sequences ${ }^{32}$ corresponding to the bases $1737-1757$ for sense ( $5^{\prime}$ GGT CAT AGG ACA CGA AAT CAC3') and 2256-2233 bases for antisense (5'TGA AGA TCA CCA AAC CCG GCA CTT3') oligonucleotide primers. The primers were designed

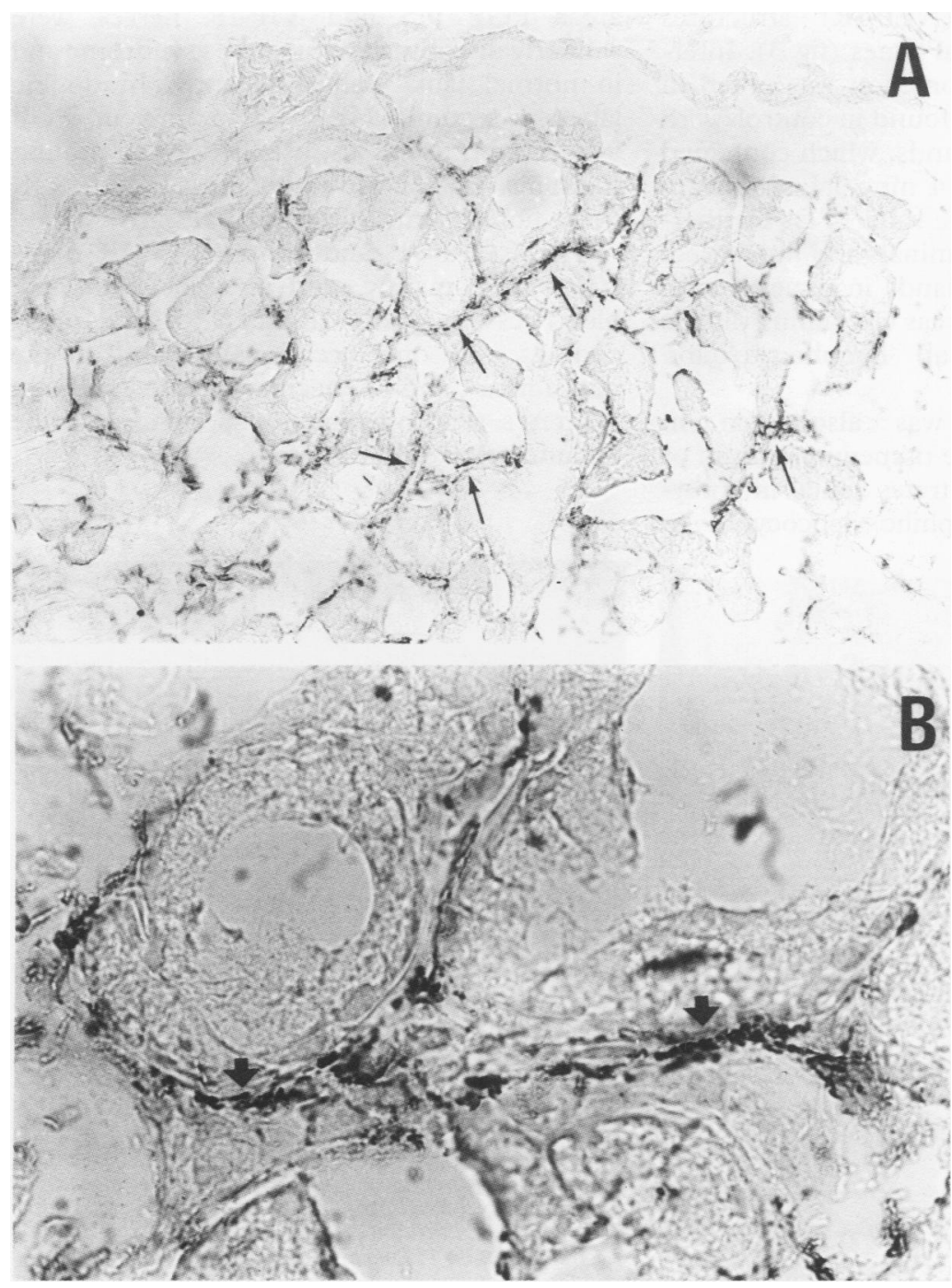

Figure 1 Avidin-biotin-peroxidase complex $(A B C)$ staining of neutral endopeptidase (NEP) with monoclonal mouse IgG, antibodies to human CD10 amplified with the glucose oxidase - nickel ammonium sulphate method without counterstaining. Nerve fibres immunoreactive (IR) to NEP in a thin $6 \mu \mathrm{m}$ tissue section are seen around the labial salivary gland acini and ducts in the form of small diameter nerve fibres, preterminal varicosities, and nerve terminals. (A) Original magnification $\times 250$; (B) original magnification $\times 1000$. so that they also recognise NEP from the proximal tubules of rabbit kidney, which was used as a positive sample control. The beads were washed once with $100 \mu l 1 \times$ PCR buffer (10 mM Tris- $\mathrm{HCl}, \mathrm{pH} 8 \cdot 8,1.5 \mathrm{mM} \mathrm{MgCl}, 50$ $\mathrm{mM} \mathrm{KCl}, 0 \cdot 1 \%$ Triton $\mathrm{X}-100)$ and the second cDNA synthesis (total reaction volume was 30 $\mu l)$ was carried out in $1 \times$ PCR buffer with $5^{\prime}$ primer $(0.42 \mu \mathrm{M}$ final) and $200 \mu \mathrm{M}$ of dATP, dCTP, dGTP, and dTTP in thin wall PCR tubes topped with $50 \mu \mathrm{l}$ mineral oil. Hot start at $80^{\circ} \mathrm{C}$ was used, $2.0 \mathrm{U}$ of the thermostable DNA polymerase (Finnzymes, Espoo, Finland) was added, samples were denatured for two minutes at $95^{\circ} \mathrm{C}$, and annealed at $61^{\circ} \mathrm{C}$ for one minute followed by five minute extension at $72^{\circ} \mathrm{C}$ with mixing at one minute intervals. After melting the strands for two minutes at $95^{\circ} \mathrm{C}$ the beads were collected with the magnet and the second strand CDNA supernatant was transferred to a new PCR tube, from which the $3^{\prime}$ primer $(0.42 \mu \mathrm{M}$ final $)$ was pipetted and 45 cycles of one minute at $95^{\circ} \mathrm{C}$, one minute at $61^{\circ} \mathrm{C}$, and one minute at $72^{\circ} \mathrm{C}$ were performed. For the last cycle a five minute extension was used (Pharmacia, Gene ATAQ Controller, Sollentuna, Sweden). Amplified DNA was run on a 1\% modified agarose gel for size verification.

\section{FLUOROPHOTOMETRY METHOD}

Salivary NEP was measured from unstimulated saliva in patients with Sjogren's syndrome $(n=7)$ and in healthy controls $(n=5)$ by using a well established activity measurement protocol. ${ }^{33}$ All samples were centrifuged immediately after collection and the supernatant was used for analysis. Briefly, $50 \mu \mathrm{l}$ of $100 \mu \mathrm{M}$ Suc-Ala-Ala-Phe-AMC in $50 \mathrm{mM}$ Tris- $\mathrm{HCl}, \mathrm{pH} 7 \cdot 6$, was incubated for one hour at $37^{\circ} \mathrm{C}$ with $150 \mu$ l of saliva diluted $1: 5$ and $1: 25$ to $50 \mathrm{mM}$ Tris- $\mathrm{HCl}, \mathrm{pH} 7 \cdot 6$, containing $0 \cdot 1 \%$ Triton X-100. Blanks contained $1 \mu \mathrm{M}$ phosphoramidon (a selective NEP inhibitor) and were run in parallel with the samples. The reaction was stopped by adding $1 \mu M$ phosphoramidon and heating at $95^{\circ} \mathrm{C}$ for 15 minutes. The Phe-AMC formed was hydrolysed completely by incubation for one hour at $56^{\circ} \mathrm{C}$ after addition of $0.75 \mu \mathrm{g}$ of aminopeptidase $M$. This reaction was stopped by heating at $95^{\circ} \mathrm{C}$ for 15 minutes. Fluorescence was measured using excitation at $367 \mathrm{~nm}$ and emission at $440 \mathrm{~nm}$.

\section{Results}

IMMUNOLOCALISATION OF NEP

In thick $20 \mu \mathrm{m}$ tissue sections NEP immunoreactivity was seen to form dense networks around the acini and ducts of the labial salivary glands. The use of thin $6 \mu \mathrm{m}$ tissue sections disclosed that NEP immunoreactivity had an appearance typical for small nerve fibres and preterminal varicosities and nerve terminals (fig 1); NEP immunoreactivity was also found in larger peripheral nerve trunks occasionally seen in labial salivary gland biopsies (fig 2). Staining of NEP in labial salivary glands of 


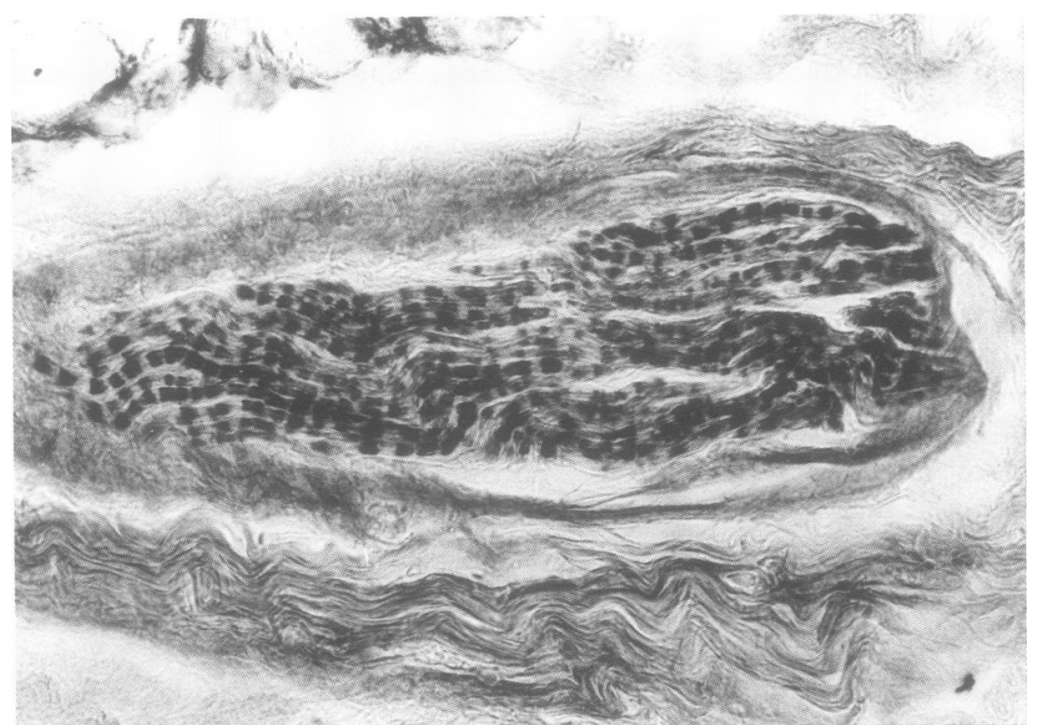

Figure 2 NEP-IR nerve trunk in a $6 \mu \mathrm{m}$ thick labial salivary gland section showing typical morphological appearance. ABC staining, glucose oxidase-nickel ammonium sulphate amplification without counterstaining. Original magnification $\times 400$.

patients with Sjögren's syndrome was otherwise similar to that of healthy controls, but focal lymphocyte infiltrates did not contain NEP-immunoreactive (NEP-IR) structures except in their peripheral zones (fig 3). Interestingly, a similar phenomenon was noted in the few foci occasionally found in controls with healthy labial salivary glands, which contained less than one focus per $4 \mathrm{~mm}^{2}$ labial salivary glands tissue (focus score value $<1$ ). Furthermore, NEP-IR nerve terminals and fibres were seen in labial salivary glands in patients with Sjögren's syndrome in areas containing diffuse (by contrast with focal) lymphocyte and plasma cell infiltration.

Occasionally NEP was also seen in fibroblast-like cells in the tissue interstitium or inflammatory cell infiltrates and in polymorphonuclear neutrophilic leucocytes in

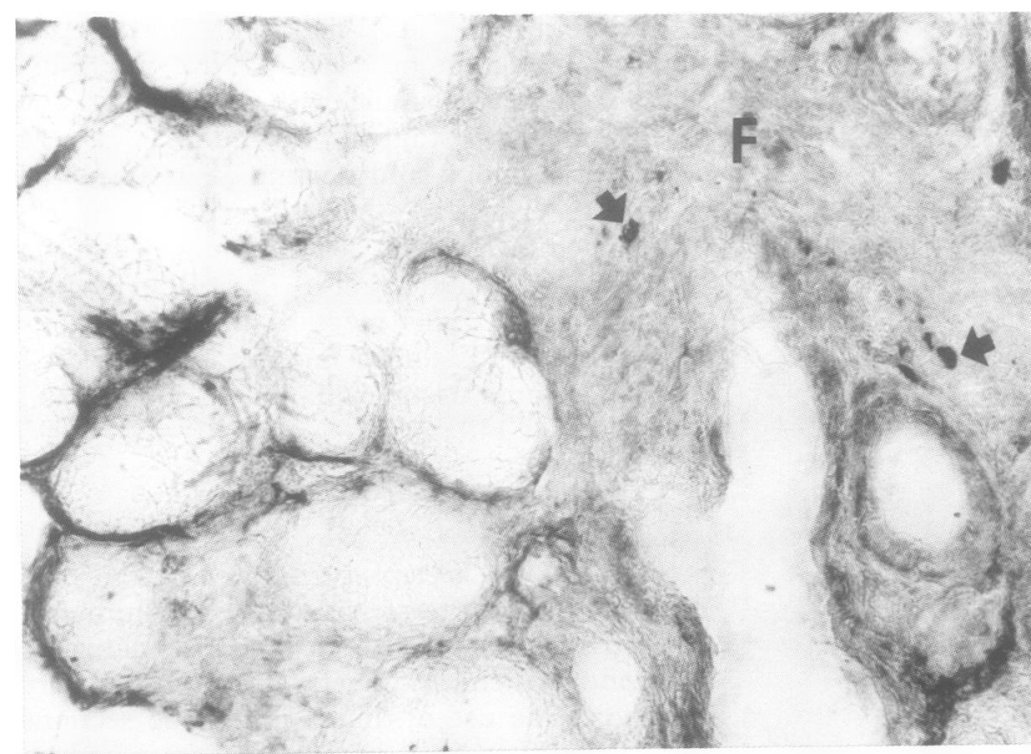

Figure 3 NEP-IR nerve fibres and varicosities around acini and ducts in a labial salivary gland from a patient with Sjögren's syndrome. As well as normal looking salivary gland tissue, this field contains a lymphocyte rich focal infiltrate $(F)$, which is a typical feature in Siögren's syndrome. The NEP-IR peripheral nerves are seen in the peripheral zones of this Sjögren's syndrome. The NEP-IR peripheral nerves are seen in the peripheral zones
lymphocyte rich infiltrate, but do not penetrate into its centre. In the midst of the lymphocytes, occasional fibroblast-like, NEP-IR mononuclear cells (arrows) are present. $A B C$ staining, glucose oxidase-nickelammonium sulphate amplification without counterstaining; original magnification $\times 400$. blood vessels (not shown). In properly processed tissue (see earlier), vascular endothelial cells, smooth muscle cells, and pericytes of the blood vessels did not show any positive NEP staining.

NEP MRNA IN LABIAL SALIVARY GLANDS

Messenger RNA coding for NEP was regularly found in positive control tissue in accordance with its synthesis in proximal tubules in epithelial cells in rabbit kidney (fig 4). By contrast, labial salivary glands from healthy controls and from patients with Sjögren's syndrome did not contain NEP mRNA (fig 4).

IMMUNOLOCALISATION OF NEUROPEPTIDES In normal labial salivary glands PGP 9.5-IR and VIP-IR fibres were seen perivascularly, around acini, and in close proximity to all salivary ducts. In patients with Sjögren's syndrome, PGP 9.5 and VIP, as NEP (see earlier), were found in the peripheral zones but not in the middle of the inflammatory cell infiltrates. Outside the focal inflammatory cell areas PGP 9.5 and VIP-IR nerves were similarly distributed in Sjögren's syndrome and in normal labial salivary glands. In double labelled sections NEP was found in PGP 9.5-IR axon terminals, usually located around the salivary acini. However, most PGP 9.5-IR nerve fibres seemed to be NEP negative.

The CGRP-IR and substance P-IR nerve fibres were mainly seen in association with blood vessels; CGRP-IR and SP-IR free nerve endings were only occasionally found in the peritubular and periacinar tissue and, in Sjögren's syndrome, in the periphery of the inflammatory cell infiltrates.

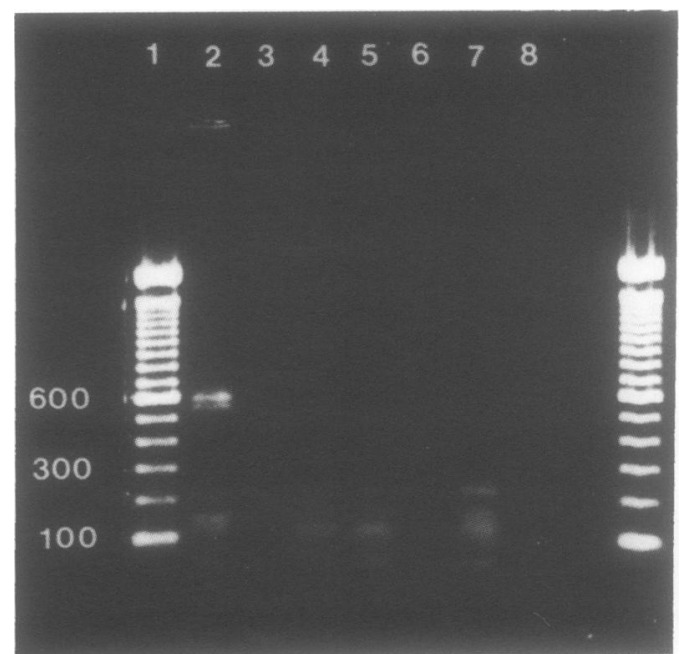

Figure 4 Representative examples of neutral endopeptidase messenger RNA amplification products after 45 cycles in the RT-PCR. Amplification products were subjected to electrophoresis on $1 \%$ modified agarose gel, stained with ethidium bromide, and photographed under UV light. The first lane contains a $100 \mathrm{bp}$ ladder; the second lane the amplification product from the proximal tubule epithelial cells in rabbit kidney. Lanes 3 to 5 contain the amplification products from labial salivary glands of healthy controls and lanes 6 to 8 the amplification products healthy controls and lanes 6 to 8 the amplification produ
from labial salivary glands of patients with Sjögren's syndrome. 
SALIVARY NEP

Analysis of activity of salivary NEP disclosed slightly higher values in patients with Sjögren's syndrome than in healthy controls. The difference, however, was not significant. The mean (SEM) $\Delta$ absorbance (samplephosphoramidon inhibited control) value at 1:5 dilution at 42 (8) (absorbance) units in patients with Sjögren's syndrome compared with 26 (13) units in healthy controls ( $p>0.05$, Mann-Whitney $U$ test) with the corresponding figures at 1:25 dilution being 21 (7) $v 9(4)(\mathrm{p}>0 \cdot 05)$.

\section{Discussion}

Neutral endopeptidase has been earlier localised to non- $T$ and non-B acute lymphocytic leukaemia cells, early lymphoid progenitor cells, germinal centre cells, fibroblasts, granulocytes, renal epithelial cells, gut epithelial cells, some lymphomas, melanomas, and glioma cell lines, and some neuronal cells. ${ }^{26}{ }^{34-36}$ In the present study specific mouse antihuman NEP antibodies used in immunohistochemical staining showed NEP in an unexpected topographical pattern in human salivary glands - namely, in the peripheral nerves. These immunohistochemical findings on NEP in labial salivary glands were supported by the demonstration of NEP in the corresponding body fluid - saliva - by using a well established activity measurement protocol. ${ }^{33}$

The endopeptidase was found in the nerve terminals and preterminal varicosities and in small diameter nerve fibres in labial salivary glands. This neuronal localisation was not evident - and would have been missed - if routine tissue processing and acetone fixation had been used. Neuronal localisation of NEP was only evident in Zamboni fixed tissues. This unexpected finding was confirmed by double labelling of NEP and PGP 9.5, a generalised neuronal cell marker. ${ }^{37}$ Furthermore, NEP was localised in large peripheral nerve trunks, which were unambiguously identified by morphological criteria. These findings were in accordance with those of Pollard and coworkers, who reported NEP in the central nervous system ${ }^{38}$; the present study is the first to show that NEP also occurs in peripheral nerves.

Localisation of NEP in large nerve trunks would be in accordance with axonal transport of NEP, which was first reported by Back and Gorenstein, based on their studies on axotomy of hypoglossal nerve. ${ }^{39}$ We hypothesised that if NEP is mainly or exclusively synthesised in nerve cell ganglia (and not in situ in labial salivary glands), the signal for NEP mRNA in labial salivary glands would be weak or negligible, even if a sensitive RT-PCR would be used for detection. This hypothesis was verified by using RT-PCR for labial salivary gland samples run in parallel with identically processed positive control samples. Despite occasional fibroblast-like NEP-IR cells, NEP mRNA was totally absent in sections of labial salivary glands. This finding indicates that labial salivary gland NEP is synthesised outside the salivary gland. Taken together, the typical varicotic appearance and tissue localisation structures containing NEP, colocalisation of NEP with a well known neuronal marker, the presence of NEP in large nerve trunks, and the absence of local synthesis, suggest that salivary gland NEP is of extraglandular, neuronal origin.

Saliva also contains NEP. This suggests that NEP, primarily synthesised as an integral cell membrane protein, is in part proteolytically cleaved and solubilised from the cell membrane and secreted into saliva. Interestingly, marker peptides of the autonomic nervous system namely, VIP and neuropeptide Y - have also been recently described in normal and Sjögren's syndrome saliva ${ }^{40}$ (Santavirta et al, unpublished observations). This may in part relate to the hypolemmal localisation of these terminal nerve fibres. ${ }^{40}$ Saliva also contains various other potential NEP substrates, such as growth factors and cytokines. Because activity measurements were used, it is not established, despite the relatively specific substrate and inhibitor used, that salivary NEP-like activity was actually exerted by NEP. On the other hand, as NEP in saliva was demonstrated based on activity, it also follows that this NEP-like activity would be able to regulate the action of various bioactive peptides produced by salivary glands for "export".

Orientation of NEP on the cell surface is such that the active site is located towards the extracellular space. It is attached to the cell membrane by a short 24 amino acid hydrophobic membrane spanning domain, which is connected to a 26 amino acid domain of unknown function on the cytoplasmic side of the plasma membrane. Distribution of NEP in the axon terminals and preterminals would seem to focus its effects on neuropeptides to the immediate perineural space. Interestingly, NEP cleaves substrates at the amino side of hydrophobic amino acids ${ }^{26}$ and its target substrates include VIP (neutral endopeptidase cleaves VIP principally into inactive VIP $_{4-28}$ and VIP $_{5-28}$ fragments, ${ }^{41}$ and substance $P$ (neutral endopeptidase can cleave SP at tree bonds, including $\mathrm{Gly}_{9}-\mathrm{Leu}_{10}$, which generates inactive fragments $\left.{ }^{26}\right)$ ).

Labial salivary glands are densely innervated by VIP-IR nerves, which are seen around acini, salivary ducts, and blood vessels. Because VIP is a trophic factor for salivary acini, lack of it causes acinar atrophy. Accordingly, surgical parasympathectomy and lack of solid food (leading to lack of mastication induced stimulation or "functional parasympathectomy") lead to acinar atrophy. Such atrophy cannot be attained by treatment with atropine to block the muscarinic acetylcholine receptors. By contrast, acinar atrophy caused by parasympathectomy can be prevented by local infusion of VIP. Recent studies have shown a close spatial relation between hypolemmal VIP-IR postganglionic parasympathetic nerves and acinar endpiece cells. ${ }^{40}$ Furthermore, acinar endpiece cells contain high affinity VIP receptors on their basal parts. ${ }^{20}$ This trophic effect of VIP represents one of the so-called non-adrenergic, 
non-cholinergic (NANC) effects of the autonomic nervous system. It was therefore of interest to localise a major VIP degrading enzyme in normal and diseased salivary glands. Both VIP and NEP were found in peripheral nerve fibres and terminals. Patients with Sjögren's syndrome had an altered tissue distribution of such structures, with lack of NEP nerves and VIP-IR nerves in lymphocyte foci. Findings were similar in the few lymphocyte foci found in normal glands. By contrast, diseased labial salivary glands from patients with Sjögren's syndrome contained NEP-IR terminals and fibres in areas diffusely infiltrated by lymphocytes and plasma cells. These findings suggest that lack of NEP-IR nerves in foci may play a part in the formation of foci rather than in the genesis of Sjögren's syndrome itself.

Focal lymphocyte infiltrates in the parenchyma of exocrine glands form a hallmark of Sjögren's syndrome. ${ }^{42}$ In the present study VIP-IR, substance P-IR, and CGRP-IR nerves were seen in the marginal zones but not in the centres of these accumulations of focal lymphocytes. Interestingly, NEP showed a similar distribution. Under these conditions, NEP could balance the proinflammatory effects of neurotransmitters. Neuropeptides released in the marginal zone of the focal lymphocyte accumulations may diffuse and act on the local inflammatory cells without being degraded by NEP. This might prolong the local half life of neuropeptides and thus augment the neurogenic component of inflammation. Substance $P$ has in fact been shown to induce the release of interleukin-1, tumour necrosis factor $\alpha$, and interleukin-6 from monocytes, ${ }^{43} 44$ whereas VIP modulates lymphocyte migration and recirculation and increases $B$ cell mediated immunoglobulin production. ${ }^{45}$ Apart from this difference between the normal and Sjögren's syndrome glands, there was no difference in topographical distribution of NEP between the two study groups. However, NEP activity was slightly but not significantly higher in saliva of patients with Sjögren's syndrome than of healthy controls, which may be due to either upregulation of neuronal NEP synthesis or, perhaps more likely, its enhanced solubilisation and secretion as a result of local inflammation.

We are grateful to Mrs Eija Kaila, Mrs Paula Hasenson, and Mrs Marja Aittamäki for their skillful technical assistance and to Mr Reijo Karppinen for producing the photographs. This study was supported by the Finnish Academy of Science, Finnish Medical Society, the Signe and Ane Gyllenberg Foundation, and the Finnish Rheumatism Research Foundation,

1 Daniels T E. Labial salivary gland biopsy in Sjögren's syndrome. Arthritis Rheum 1984; 27: 147-56.

syndrome. Arthritis Rheum 1984; 27: 147-56.
2 Fox R I, Howell F V, Bone R C, Michelson P. Primary Sjögren's syndrome: clinical and immunopathological features. Semin Arthritis Rheum 1984; 14: 77-105.

3 Konttinen Y T, Segerberg-Konttinen M, Bergroth V, Malmström M. Pathogenesis of Sjögren's syndrome. Scand $\mathcal{F}$ Rheumatol (suppl) 1986; 61: 61-6.

4 Scully C. Sjögren's syndrome: clinical and laboratory features, immunopathogenesis and management. Oral Surg Oral Med Oral Pathol 1986; 62: 510-23.

5 Manthorpe R, Oxholm P, Prause J U, Schiødt M. The Cophenhagen criteria for Sjögren's syndrome. Scan $\mathcal{f}$ Rheumatol (suppl) 1986; 61: 19-21.

6 Moutsopoulos H M, Chused T M, Mann D L, et al. Sjögren's syndrome (sicca syndrome): current issues. $A n n$ Intern Med 1980; 92: 212-26.

7 Emmelin N. Nerve interactions in salivary glands. 7 Dent Res 1987 ; 66: 509-17.
8 Garret J R. The proper role of nerves in salivary secretion: a review. $\mathcal{F}$ Dent Res 1987; 66: 387-97.

9 Schneyer C A, Hall H D. Function of rat parotid gland after sympathectomy and total postganglionectomy. $\mathrm{Am} f$ Physiol 1966; 211: 943-9.

10 Schneyer C A. Autonomic regulation of secretion and growth. In: Thorn N A, Petersen O H. Secretory mechan-
isms of exocrine glands. Copenhagen: Munksgaard, 1974.

11 Ekström J. Choline acetyltransferase activity in rat salivary glands after cellulose rich diet or treatment with atropine-like drug. $Q \ngtr$ Exp Physiol 1974; 59: 191-9.

12 Ekström J, Månsson $\mathrm{B}$, Tobin $\mathrm{G}$, Garret $\mathrm{J}$ R, Thulin A Atropine-resistant secretion of parotid saliva on stimulation of the auriculo-temporal nerve. Acta Physiol Scand 1983; 119: 445-9.

13 Burgen A S V, Emmelin N. Physiology of salivary glands. London: Arnold, 1961

14 Bobyock E, Barbieri E J, Chernick W S. Effects of substance $P$ and substance $P$ antagonist on rat salivary secretion. $f$ Dent Res 1986; 65: 1427-31.

15 Gallager D V. Substance $P$ is a functional neurotransmitter in the rat parotid gland. $\mathcal{F}$ Physiol 1983; 342: 483-98.

16 Ekström J, Olgart L. Complementary action of substance $P$ and vasoactive intestinal peptide on the rat parotid secretion. Acta Physiol Scand 1986; 126: 25-31.

17 Ekström J. Neuropeptides and secretion. $\mathcal{F}$ Dent Res 1987; 66: 524-30.

18 Konttinen Y T, Sorsa $T$, Hukkanen $M$, Segerberg $M$, et al. Topology of innervation of labial salivary glands by propology of innervation of labial salivary glands by protein gene product 9.5 and synaptophysin immunoreactive nerves in patients
Rheumatol 1992; 19: 30-7.

19 Konttinen Y T, Hukkanen M, Kemppinen P, et al. Peptidecontaining nerves in labial salivary glands in patients with Siögren's syndrome. Arthritis Rheum 1992; 35: 815-20.

20 Törnwall J, Uusitalo $H$, Hukkanen $M$, Sorsa $T$, Konttinen Y T. Distribution of vasoactive intestina peptide (VIP) and its binding sites in labial salivary glands in Sjögren's syndrome and in healthy controls. Clin Exp Rheumatol 1994; 12: 287-92.

21 Shipp M A, Richardson N E, Sayre P H, et al. Molecular cloning of the common acute lymphoblastic leukaemia cloning of the common acute lymphoblastic leukaemia protein. Proc Natl Acad Sci USA 1988; 85: 4819-23.

22 Devault A, Lazure C, Nault C, et al. Aminoacid sequence of rabbit kidney neutral endopeptidase 24.11 (enkephalinase) deduced from a complementary DNA $E M B O \mathcal{F}$ 1987; 6: 1317-22.

23 Malfroy B, Schofield P R, Kuang W-J, Seeburg P H, Mason A J, Henzel W J. Molecular cloning and amino acid sequence of rat enkephalinase. Biochem Biophys Res Commun 1987; 144: 59-66.

24 Malfroy B, Kuang W-J, Seeburg P H, Mason A J Schofield $P$ R. Molecular cloning and amino acid sequence of human enkephalinase (neutral endopeptidase). FEBS Lett 1988; 229: 206-10.

25 Turner A J. Endopeptidase-24.11 and neuropeptide metabolism. In: Turner A J, ed. Neuropeptides and their metabolism. In: Turner A J, ed. Neuropeptides and their

26 Kerr M A, Kenny A J. Purification and specificity of neutral endopeptidase from rabbit kidney brush border. Biochem $\mathcal{F} 1974 ; 137: 477-88$.

27 Kerr M A, Kenny A J. The molecular weight and properties of neutral metallo-endopeptidase from rabbit kidney brush border. Biochem f 1974; 137: 489-95.

28 Skidgel R A, Engelbrecht A, Johnson A R, Erdös E G. Hydrolysis of substance $P$ and neurotensin by converting enzyme and neutral endopeptidase. Peptides 1984; $5:$ 769-76.

29 Connelly J C, Skidgel R A, Schultz W W, Johnson A R, Erdös E G. Neutral endopeptidase 24.11 in human neutrophils: cleavage of chemotactic peptide. Proc Natl neutrophils: cleavage of chemotacti

30 Gafford J T, Skidgel R A, Erdös E G, Hersh L B. Human kidney "enkephalinase", a neutral metalloendopeptidase that cleaves active peptides. Biochemistry 1983; 22: 3265-71.

$31 \mathrm{Hsu} S \mathrm{M}$, Raine L, Fanger H. Use of avidin-biotinperoxidase complex (ABC) in immunoperoxidase technique: a comparison between $\mathrm{ABC}$ and unlabelled antibody (PAP) procedures. F Histochem Cytochem 1981; 29: $577-80$.

32 D'Adamio L, Shipp M A, Masteller E L, Reinherz E L. Organization of the gene encoding common acute lymphoblastic leukemia antigen (neutral endopeptidase 24.11): multiple miniexons and spearate $5^{\prime}$ untranslated 24.11): multiple miniexons and spearate 5' untran
regions. Proc Natl Acad Sci USA 1989; 86: 7103-7.

33 Spillantini M G, Gepetti P, Fanciullacci M, Michelacci S, Lecomte J M, Sicuteri F. In vivo "enkephalinase" inhbition by acetorphan in human plasma and CSF. Eur inhbition by acetorphan in hum

34 Fulcher I A, Chaplin M F, Kenny A J. Endopeptidase 24.11 purified from pig intestine is differently glycosylated from purified from pig intestine is differently glycosylated
that in the rat kidney. Biochem $\Im 1983 ; 215: 317-23$.

35 Bowes M A, Kenny A J. Endopeptidase 24.11 in pig lymph nodes. Biochem f 1986; 236: 801-10.

36 Bunnett N W Turner A J, Hryszko J. Isolation of endopeptidase 24.11 from pig stomach. Gastroenterology 1988; 95: 952-7.

37 Wilkinson KD, Lee KM, Deshpande S, Duerksen-Hughes $P$, Boss J M, Pohl J. The neuron-specific protein PGP 9.5 is an ubiquitin carboxyl-terminal hydrolase. Science 1989; 246: 670-3.

38 Pollard H, Bouthenet M L, Moreau J, et al. Detailed immunoautoradiographic mapping of enkephalinase in 
rat central nervous system: comparison with enkephalins and substance P. Neuroscience 1989; 30: 339-76.

39 Back S A, Gorenstein C. Differential response of neutral endopeptidase 24.11 ("enkephalinase"), and cholinergic and opioidergic markers to hypoglossal axotomy. $\mathcal{F} \operatorname{Com} p$ Neurol 1994; 340: 149-60.

40 Törnwall J, Konttinen YT, Hietanen J, Sorsa T, Hukkanen $M$, Uusitalo H VIP in salivary glands in Sjögren's syndrome. Br f Rheumatol 1995; 34: 891-3.

41 Goetzl E J, Sreedharan S P, Turck C W, Bridenbaugh R, Malfroy B. Preferential cleavage of amino- and carboxylterminal oligopeptides from vasoactive intestinal terminal oligopeptides from vasoactive intestinal polypeptide by human recombinant enkephalinase
(neutral endopeptidase, EC 3.4.24.11). Biochem Biophys Res Commun 1989; 158: 850-4.
42 Greenspan J S, Daniels T E, Talal N, Sylvester T A. The histopathology of Sjögren's syndrome in labial salivary gland biopsies. Oral Surg Oral Med Oral Pathol 1974; 37: 217-29.

43 Lotz M, Carson D A, Vaughan J H. Substance P activation of rheumatoid synoviocytes: neural pathway in pathogenesis of arthritis. Science 1987; 235: 893-5.

44 Lotz M, Vaughan J H, Carson D A. Effect of neuropeptides on production of inflammatory cytokines by human on production of inflammatory cytokin

45 Stanisz A M, Befus D, Bienenstock J. Differential effect of vaso-active intestinal peptide, substance $P$ and somavaso-active intestinal peptide, substance $P$ and soma-
tostatin on immunoglobulin synthesis and proliferation by tostatin on immunoglobulin synthesis and proliferation by
lymphocytes from Peyer's patches, mesenteric lymph nodes and spleen. $\mathcal{F}$ Immunol 1987; 136: 152-6. 